\title{
Screening the efficacy of extracts of different spices in inhibiting the growth of foodborne bacterial isolates
}

\author{
${ }^{1, *}$ Munshi, S.K., ${ }^{1}$ Abokor, A.O., ${ }^{1}$ Islam, T., ${ }^{1}$ Ishma, T., ${ }^{1}$ Nur, I.T., ${ }^{1}$ Ahmmed, J., ${ }^{1}$ Akter, T., \\ ${ }^{1}$ Shewly, S.R. and ${ }^{2}$ Paul, S. \\ ${ }^{1}$ Department of Microbiology, Stamford University Bangladesh, 51, Siddeswari Road, Dhaka 1217, \\ Bangladesh \\ ${ }^{2}$ Quality Assurance and Research and Development, Dhaka Ice Cream Industries Ltd., 80, Shaheed \\ Tajuddin Ahmed Sarani, Tejgaon I/A, Dhaka 1208, Bangladesh
}

\begin{abstract}
Article history:
Received: 28 April 2021

Received in revised form: 13

May 2021

Accepted: 10 June 2021

Available Online: 23 January

2022

Keywords:

Antimicrobial activity,

Foodborne bacteria,

Food contamination,

Food preservation,

Solvent extracts,

Spices
\end{abstract}

DOI:

https://doi.org/10.26656/fr.2017.6(1).289

\begin{abstract}
Owing to the presence of a diverse group of phytochemicals, spices could be potential sources of antibacterial and antioxidant agents. The present investigation was aimed to determine and compare the antimicrobial activities of different spices. A total of 5 spices including cardamom (Seeds, Elettaria cardamomum), cinnamon (Barks, Cinnamomum verum), clove (Flower buds, Syzygium aromaticum), Indian bay leaf or Tejpat (Dried leaves, Cinnamomum tamala), and cumin (Seeds, Cuminum cyminum) were collected. Different extracts (crude, aqueous, ethanolic, and methanolic) of spices were prepared and examined for antimicrobial activity against previously isolated foodborne bacterial isolates. Extracts from the tested spices showed significant inhibitory effects (mostly with $>10 \mathrm{~mm}$ mean zone of inhibition) as revealed by the agar well diffusion technique. Clove among the tested spices was found to be the prominent one in eliminating foodborne pathogens. Methanolic extracts followed by ethanolic extracts were determined to be most effective against the bacterial isolates when the relative effectivity of different extracts was compared. The frequently encountered minimal inhibitory and bactericidal concentrations of the spices were 12 and $24 \mathrm{mg} / \mathrm{mL}$, respectively. All the spice extracts showed considerable antimicrobial traits which validate their potential and applicability as natural food preservatives and decontaminants.
\end{abstract}

\section{Introduction}

Despite the food safety concern and recent technological advancements, foodborne diseases remain to be a big concern worldwide as well as in Bangladesh (Gottardi et al., 2016; Noor and Feroz, 2016). Several microorganisms responsible for food spoilage and foodborne illnesses can frequently contaminate foods from various sources such as water, air, dust, equipment, sewage, insects, rodents, and personnel(Chakraborty et al., 2020). To ensure food safety and quality, controlling the growth of spoiling and pathogenic foodborne microorganisms is crucial. Suppression of one or more essential factors associated with microbial survival could ensure food conservation (de Souza et al., 2005). However, synthetic preservatives that have been used in foods for decades could be toxic to humans and may have adverse health consequences (de Souza et al., 2005; Chakraborty et al., 2020). Therefore, the concern for replacing synthetic preservatives with renewable, effective, and non-toxic compounds is raising (de Souza et al., 2005; Purkait et al., 2018). Especially plant products with antimicrobial properties attract special focus for potential use in food processing to control bacterial and fungal growth (Jahan et al., 2018; Hossaini et al., 2020; Hossaini et al., 2021). Plant-derived antimicrobial compounds have been used for food preservation for centuries (Dhiman et al., 2016).

Since ancient times, spices have been used to heighten the flavour and taste of cooked food (D'Souza et al., 2017). Spices are usually dry, colourful, aromatic, pungent, and used as seasoning agents applied in minimal amounts (de Souza et al., 2005; D'Souza et al., 2017). Spices comprise different plant materials including leaves, flowers, fruits, roots, rhizomes, bulbs and more(de Souza et al., 2005; Chakraborty et al., 2020). Spices and their combination constitute naturally occurring food additives and are an integral part of the daily diets of large numbers of the world's population 
(Škrinjar and Nemet, 2009). Some spices are known to have antibacterial and antioxidant effects. They aid in the prevention and treatment of a range of diseases such as cancer, ageing, metabolic, neurological, cardiovascular, and inflammatory disorders (Teodoro, 2019). Their role in food safety and preservation has also been established (Gottardi et al., 2016).

Spices can assist in food preservation and food safety maintenance by imparting antimicrobial and antioxidant properties against food spoilage and foodborne pathogenic microorganisms (Tajkarimi et al., 2010; Gottardi et al., 2016). Thereby, they can enhance the shelf-life of foods (Shan et al., 2007; Diman et al., 2016). Several active compounds such as phenolic compounds, carvacrol, eugenol, carvone, thymol, transcinnamaldehyde, and gingerol have been identified to have antimicrobial and antioxidant potential (Chakraborty et al., 2020). However, frequent evaluation of the antimicrobial activity of different spices against foodborne microorganisms is crucial to claim their effectiveness as food preservatives (Chakraborty et al., 2020). Therefore, the present study was undertaken to examine the inhibitory potential of spices commonly used in Bangladesh against foodborne bacteria through agar well diffusion and microdilution methods.

\section{Materials and methods}

\subsection{Samples}

Five categories of commonly used spices, Cardamom (Seeds, Elettaria cardamomum), Cinnamon (Barks, Cinnamomum verum), Clove (Flower buds, Syzygium aromaticum), Indian Bay Leaf or Tejpat (Dried leaves, Cinnamomum tamala), and Cumin (Seeds, Cuminum cyminum) were collected from the local market of Dhaka, Bangladesh during October 2020 to December 2020. Following collection, samples were quickly transported to the laboratory of the Department of Microbiology, Stamford University Bangladesh. They were allowed to dry then processed for extraction.

\subsection{Preparation of spice extracts}

Each spice sample (dried) was blended to get the powdered form which was directly employed as a crude fraction. The aqueous extract was prepared by adding 10 $\mathrm{g}$ of each sample powder to the $90 \mathrm{~mL}$ of buffer peptone water followed by homogenization. The solvent extracts (ethanolic and methanolic) were prepared by mixing $15 \mathrm{~g}$ of each powdered spice sample to $85 \mathrm{~mL}$ of ethanol and methanol in separate Durham's bottles that were kept in a shaking water bath at $130 \mathrm{rpm}$ for $24-48 \mathrm{hrs}$ at $24^{\circ} \mathrm{C}$. Afterwards, the solvent extracts were filtered using Whatman filter papers. The filtered extracts were then kept in a rotary evaporator for evaporation of methanol and ethanol followed by dissolving the extracts in $10 \%$ dimethyl sulfoxide (DMSO) to make a final concentration of $10 \mathrm{mg} / \mathrm{mL}$ (Jahan et al., 2018; Chakraborty et al., 2020; Hossaini et al., 2020; Hossaini et al., 2021). The extracts were stored at $4^{\circ} \mathrm{C}$ until use.

\subsection{Test microorganisms}

The bacterial isolates used in this study for the antimicrobial assay were previously isolated and biochemically identified from different food samples including fried chicken, chicken sausage, ice creams and mango juices in the laboratory of the Department of Microbiology, Stamford University Bangladesh employing standard protocol for microbiological analysis (Akter et al., 2019; Hossain et al., 2020; Hossaini et al., 2020). The selected foodborne bacterial isolates include Escherichia coli, Klebsiella spp., Pseudomonas spp., Vibrio spp., Listeria spp., Salmonella spp. and Staphylococcus spp. bacteria were preserved at $-20^{\circ} \mathrm{C}$ and subcultures were made on Nutrient agar (HiMedia Laboratories, Mumbai, India) before tested in the current study.

\subsection{Determination of the antimicrobial activity of spice} extracts by agar well diffusion method

Modified agar well diffusion method (Sharmin et al., 2014; Munshi et al., 2018; Chakraborty et al., 2020; Hossaini et al., 2020; Hossaini et al., 2021; Kabir et al., 2021) was applied to determine the anti-bacterial potential of crude fraction, aqueous and solvent extracts of the spice samples against different previously isolated foodborne bacterial strains. First, the lawn was prepared on Mueller-Hinton agar (MHA, Oxoid Ltd., England) by spreading each bacterial suspension (turbidity adjusted to the $0.5 \mathrm{McF}$ arland standard which is equal to $10^{5} \mathrm{CFU} /$ $\mathrm{mL})$ and wells $(8 \mathrm{~mm})$ were made after the media dried. Crude fractions, aqueous, ethanolic, and methanolic extracts at a residual concentration of $10 \mathrm{mg} / \mathrm{mL}$ were introduced into the wells generated on MHA. Buffer peptone water, absolute ethanol, and methanol were used as negative controls, whereas Gentamicin antibiotic disc $(10 \mu \mathrm{g})$ was used as a positive control. After incubation at $37^{\circ} \mathrm{C}$ for $12-18 \mathrm{hrs}$, the plates were examined for the formation of a zone of inhibition ( $\mathrm{mm}$ ) around the wells.

2.5 Assessment of the minimal inhibitory concentration (MIC) and minimal bactericidal concentration (MBC) of spices

For the determination of the minimal inhibitory and bactericidal concentrations of the spice samples, the microdilution method was employed(Sharmin et al., 2014; Hossaini et al., 2020; Hossaini et al., 2021; Kabir et al., 2021). After overnight ( 12 hrs) incubation, 100 $\mu \mathrm{L}$ of each bacterial suspension (turbidity adjusted to 0.5 
McFarland standard) was inoculated into properly labelled tubes containing $3 \mathrm{~mL}$ Mueller-Hinton (MH) broth (Oxoid Ltd., England). Spice samples were further added into the suspension at residual concentrations of $1.5,3,6,12,24$, and $48 \mathrm{mg} / \mathrm{mL}$, and the tubes were incubated at $37^{\circ} \mathrm{C}$ for $18-24 \mathrm{hrs}$. The lowest concentration $(\mathrm{mg} / \mathrm{mL})$ of each sample that could visibly inhibit the growth of the tested bacteria was considered as the MIC value and the lowest concentration $(\mathrm{mg} / \mathrm{mL})$ that could clear the growth i.e to kill the tested bacteria was determined as the MBC value (Sharmin et al., 2014; Hossaini et al., 2020; Hossaini et al., 2021).

\subsection{Statistical analysis}

All the experiments carried out in this study were in triplicate. Statistical analysis was conducted using SPSS statistics version 20.0 (IBM, Georgia, USA) and Microsoft Office Excel Professional Plus 2016 (Microsoft Corporation, Redmond, Washington, USA) program packages, and the mean values and standard deviations (SD) were determined. Data were analyzed by one-way ANOVA, and mean values were separated by the posthoc statistic of Tukey's HSD (honest significant difference). The mean differences in the results of different extracts were considered to be significant at $\mathrm{P}<$ 0.05 .

\section{Results and discussion}

\subsection{Antimicrobial potential of the tested spices}

All the spice samples showed their efficiency in reducing the growth of foodborne bacterial isolates and significant differences $(\mathrm{P}<0.05)$ were observed in the mean zone of inhibition $(\mathrm{mm})$ by different extracts (Table 1). In most cases, ethanolic and methanolic extracts were successful in exhibiting their antimicrobial potential to a significant extent. Whereas, crude fractions and aqueous extracts except for Cloves were found to impart no activity against a majority of the tested bacterial isolates (Table 1). Mean \pm SD zone of inhibition found for different extracts of Cardamoms was minimal with the highest measurement of $12.7 \pm 1.53 \mathrm{~mm}$ and no effect was found against Vibrio cholerae (Table 1). However, Tajkarimi et al. (2010) and Savan and Kucukbay (2013) reported antimicrobial potential in Cardamom against a range of bacterial isolates from food samples. The extracts of Cinnamons, especially the ethanolic and methanolic extracts, had antimicrobial activity against the foodborne bacterial isolates with mean \pm SD zone of inhibition ranging from $9.3 \pm 0.58 \mathrm{~mm}$ to $18.0 \pm 1.00 \mathrm{~mm}$. Tajkarimi et al. (2010) and Purkait et al. (2018) found Cinnamon to be effective against both Gram-positive and Gram-negative bacteria isolated from spoiled and contaminated foods. With the inhibitory zones ranging from $7.3 \pm 0.58 \mathrm{~mm}$ to $15.3 \pm 1.15 \mathrm{~mm}$, ethanolic and methanolic extracts of Indian Bay Leaf samples had noticeable antimicrobial activity though crude fraction and aqueous extract merely had any effect. Nearly similar findings were found for the Cumin samples with mean $\pm \mathrm{SD}$ zone of inhibition ranging from $7.7 \pm 0.58 \mathrm{~mm}$ to $15.7 \pm 1.53 \mathrm{~mm}$ (Table 1). Tajkarimi et al.(2010) and $\mathrm{Xu}$ et al.(2014) evident antimicrobial efficacy in Indian bay leaf against food spoilage bacterial isolates. Al-Jedah et al.(2000) found a static effect in Cumin against different bacteria of fish sauce. A study by Wakoli et al.(2014) had evidence of the control of food spoilage by Cumin. However, Purkait et al.(2018) found Cumin to be ineffective against Gram-negative bacteria.

Clove was proved to be the most effective spice among the tested samples in retarding the growth of bacteria as all the extracts including crude fraction and aqueous extract imparted remarkable inhibitory effects with the highest $25.7 \pm 0.58 \mathrm{~mm}$ inhibition zone (Table 1 ). Zhang et al.(2009) found a strong inhibitory effect in Clove against meat spoilage bacteria. Several other researchers also reported significant antimicrobial activity in Clove against foodborne bacterial isolates (Leuchner and Zamparini, 2009; Shan et al., 2007). Similar to the findings of the present study, Chouhan et al.(2017) and Purkait et al.(2018) also found higher antimicrobial potential in Clove than other tested spices against foodborne bacteria. The methanolic extract was found to be most effective in eliminating the growth of foodborne bacteria. in cohort with the findings of previous studies (Shan et al., 2007; Negi, 2012; Dhiman et al., 2016).

\subsection{The MIC and MBC of the spices}

The MIC of the spice samples against the foodborne bacterial isolates was ranged between 6 and $48 \mathrm{mg} / \mathrm{mL}$ (Figure 1). In the majority of the cases (21 instances), the MIC was found to be $12 \mathrm{mg} / \mathrm{mL}$. The MIC of $24 \mathrm{mg} / \mathrm{mL}$

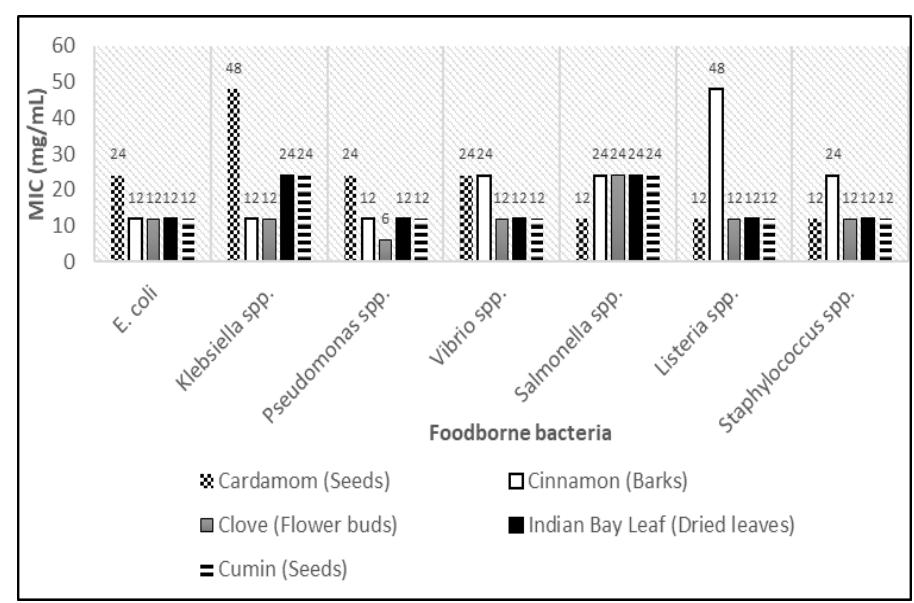

Figure 1. Minimum inhibitory concentration (MIC) of the spice samples. Mean values have been shown here. 
Table 1. Antimicrobial potential of different extracts of the tested spices.

\begin{tabular}{|c|c|c|c|c|c|c|}
\hline \multirow[b]{2}{*}{ Spices } & \multirow[b]{2}{*}{ Foodborne bacteria } & \multicolumn{4}{|c|}{ Zone of inhibition in diameter (mm) } & \multirow{2}{*}{$\begin{array}{c}\text { Positive control } \\
(\text { Gentamicin } 10 \mu \mathrm{g})\end{array}$} \\
\hline & & Crude fraction & $\begin{array}{c}\text { Aqueous } \\
\text { extract }\end{array}$ & $\begin{array}{c}\text { Ethanolic } \\
\text { extract }\end{array}$ & $\begin{array}{c}\text { Methanolic } \\
\text { extract }\end{array}$ & \\
\hline \multirow{7}{*}{$\begin{array}{c}\text { Cardamom } \\
\text { (Seeds, Elettaria } \\
\text { cardamomum) }\end{array}$} & E. coli & $0 \pm 0$ & $0 \pm 0$ & $6.7 \pm 0.58^{\mathrm{dx}}$ & $6.7 \pm 1.15^{\mathrm{ex}}$ & $18.7 \pm 0.58^{\mathrm{ax}}$ \\
\hline & Klebsiella spp. & $0 \pm 0$ & $0 \pm 0$ & $8.3 \pm 0.58^{\mathrm{dy}}$ & $8.7 \pm 0.58^{\mathrm{ey}}$ & $21.0 \pm 1.00^{\mathrm{ay}}$ \\
\hline & Pseudomonas spp. & $0 \pm 0$ & $0 \pm 0$ & $11.7 \pm 0.58^{\mathrm{dz}}$ & $0 \pm 0$ & $21.7 \pm 0.58^{\mathrm{az}}$ \\
\hline & Vibrio spp. & $0 \pm 0$ & $0 \pm 0$ & $0 \pm 0$ & $0 \pm 0$ & $19.7 \pm 0.58^{\mathrm{au}}$ \\
\hline & Salmonella spp. & $0 \pm 0$ & $0 \pm 0$ & $6.7 \pm 1.53^{\mathrm{dv}}$ & $7.0 \pm 1.00^{\mathrm{ev}}$ & $20.0 \pm 1.00^{\mathrm{av}}$ \\
\hline & Listeria spp. & $0 \pm 0$ & $12.7 \pm 0.58^{\mathrm{cw}}$ & $8.7 \pm 0.58^{\mathrm{dw}}$ & $12.7 \pm 1.53^{\mathrm{ew}}$ & $23.3 \pm 0.58^{\text {aw }}$ \\
\hline & Staphylococcus spp. & $0 \pm 0$ & $0 \pm 0$ & $10.3 \pm 0.58^{\mathrm{dt}}$ & $6.7 \pm 0.58^{\mathrm{et}}$ & $22.7 \pm 0.58^{\text {at }}$ \\
\hline \multirow{7}{*}{$\begin{array}{c}\text { Cinnamon } \\
\text { (Barks, } \\
\text { Cinnamomum } \\
\text { verum) }\end{array}$} & E. coli & $0 \pm 0$ & $0 \pm 0$ & $9.7 \pm 0.58^{\mathrm{dx}}$ & $13.7 \pm 0.58^{\mathrm{ex}}$ & $19.7 \pm 0.58^{\mathrm{ax}}$ \\
\hline & Klebsiella spp. & $0 \pm 0$ & $0 \pm 0$ & $9.7 \pm 1.15^{\mathrm{dy}}$ & $15.7 \pm 0.58^{\mathrm{ey}}$ & $20.3 \pm 1.15^{\text {ay }}$ \\
\hline & Pseudomonas spp. & $0 \pm 0$ & $0 \pm 0$ & $11.3 \pm 1.15^{\mathrm{dz}}$ & $13.7 \pm 0.58^{\mathrm{ez}}$ & $20.7 \pm 0.58^{\mathrm{az}}$ \\
\hline & Vibrio spp. & $0 \pm 0$ & $9.3 \pm 0.58^{\mathrm{au}}$ & $9.7 \pm 0.58^{\mathrm{du}}$ & $18.0 \pm 1.00^{\mathrm{eu}}$ & $18.7 \pm 0.58^{\text {au }}$ \\
\hline & Salmonella spp. & $0 \pm 0$ & $0 \pm 0$ & $9.3 \pm 1.15^{\mathrm{dv}}$ & $13.3 \pm 0.58^{\mathrm{ev}}$ & $19.3 \pm 0.58^{\mathrm{av}}$ \\
\hline & Listeria spp. & $18.3 \pm 0.58^{\mathrm{bw}}$ & $11.0 \pm 1.00^{\mathrm{cw}}$ & $15.0 \pm 1.00^{\mathrm{dw}}$ & $16.7 \pm 1.15^{\mathrm{ew}}$ & $22.0 \pm 1.00^{\mathrm{aw}}$ \\
\hline & Staphylococcus spp. & $19.3 \pm 1.15^{\mathrm{bt}}$ & $0 \pm 0$ & $10.3 \pm 1.53^{\mathrm{dt}}$ & $10.7 \pm 0.58^{\mathrm{et}}$ & $21.3 \pm 0.58^{\mathrm{at}}$ \\
\hline \multirow{7}{*}{$\begin{array}{c}\text { Clove } \\
\text { (Flower buds, } \\
\text { Syzygium } \\
\text { aromaticum) }\end{array}$} & E. coli & $20.3 \pm 1.53^{b x}$ & $9.7 \pm 0.58^{\mathrm{cx}}$ & $20.7 \pm 1.15^{\mathrm{dx}}$ & $19.7 \pm 0.58^{\mathrm{ex}}$ & $19.3 \pm 1.15^{\mathrm{ax}}$ \\
\hline & Klebsiella spp. & $25.7 \pm 0.58^{\text {by }}$ & $11.7 \pm 0.58^{\text {cy }}$ & $15.7 \pm 0.58^{\mathrm{dy}}$ & $22.3 \pm 1.15^{\mathrm{ey}}$ & $21.7 \pm 0.58^{\text {ay }}$ \\
\hline & Pseudomonas spp. & $18.7 \pm 0.58^{\mathrm{bz}}$ & $11.3 \pm 1.15^{\mathrm{cz}}$ & $20.0 \pm 1.00^{\mathrm{dz}}$ & $16.7 \pm 0.58^{\mathrm{ez}}$ & $21.7 \pm 0.58^{\mathrm{az}}$ \\
\hline & Vibrio spp. & $21.0 \pm 1.00^{\mathrm{bu}}$ & $11.7 \pm 0.58^{\mathrm{cu}}$ & $18.7 \pm 0.58^{\mathrm{du}}$ & $21.7 \pm 0.58^{\mathrm{eu}}$ & $20.0 \pm 1.00^{\mathrm{au}}$ \\
\hline & Salmonella spp. & $19.7 \pm 0.58^{\text {bv }}$ & $15.3 \pm 1.15^{\mathrm{av}}$ & $17.7 \pm 0.58^{\mathrm{dv}}$ & $19.7 \pm 0.58^{\mathrm{ev}}$ & $19.7 \pm 0.58^{\mathrm{av}}$ \\
\hline & Listeria spp. & $25.3 \pm 1.15^{\text {bw }}$ & $10.7 \pm 0.58^{\mathrm{cw}}$ & $16.3 \pm 1.15^{\mathrm{dw}}$ & $23.7 \pm 0.58^{\mathrm{ew}}$ & $21.0 \pm 1.00^{\mathrm{aw}}$ \\
\hline & Staphylococcus spp. & $24.7 \pm 0.58^{\mathrm{bt}}$ & $14.7 \pm 0.58^{\mathrm{ct}}$ & $23.7 \pm 0.58^{\mathrm{dt}}$ & $24.3 \pm 1.53^{\mathrm{et}}$ & $22.7 \pm 0.58^{\text {at }}$ \\
\hline \multirow{7}{*}{$\begin{array}{c}\text { Indian Bay Leaf } \\
\text { (Dried leaves, } \\
\text { Cinnamomum } \\
\text { tamala) }\end{array}$} & E. coli & $0 \pm 0$ & $0 \pm 0$ & $10.3 \pm 0.58^{\mathrm{dx}}$ & $9.7 \pm 0.58^{\mathrm{ex}}$ & $19.0 \pm 1.00^{\mathrm{ax}}$ \\
\hline & Klebsiella spp. & $0 \pm 0$ & $0 \pm 0$ & $0 \pm 0$ & $10.3 \pm 1.15^{\mathrm{ey}}$ & $21.3 \pm 0.58^{\text {ay }}$ \\
\hline & Pseudomonas spp. & $0 \pm 0$ & $0 \pm 0$ & $11.3 \pm 1.15^{\mathrm{dz}}$ & $10.7 \pm 0.58^{\mathrm{ez}}$ & $20.7 \pm 0.58^{\mathrm{az}}$ \\
\hline & Vibrio spp. & $0 \pm 0$ & $0 \pm 0$ & $7.7 \pm 0.58^{\mathrm{du}}$ & $10.7 \pm 0.58^{\mathrm{eu}}$ & $20.7 \pm 0.58^{\text {au }}$ \\
\hline & Salmonella spp. & $0 \pm 0$ & $0 \pm 0$ & $7.3 \pm 1.15^{\mathrm{dv}}$ & $14.7 \pm 0.58^{\mathrm{ev}}$ & $20.3 \pm 1.15^{\mathrm{av}}$ \\
\hline & Listeria spp. & $0 \pm 0$ & $14.7 \pm 0.58^{\mathrm{cw}}$ & $14.7 \pm 0.58^{d w}$ & $15.3 \pm 1.15^{\mathrm{ew}}$ & $21.3 \pm 0.58^{\mathrm{aw}}$ \\
\hline & Staphylococcus spp. & $0 \pm 0$ & $0 \pm 0$ & $7.3 \pm 0.58^{\mathrm{dt}}$ & $8.7 \pm 0.58^{\mathrm{et}}$ & $22.3 \pm 0.58^{\mathrm{at}}$ \\
\hline \multirow{7}{*}{$\begin{array}{c}\text { Cumin } \\
\text { (Seeds, Cuminum } \\
\text { cyminum) }\end{array}$} & E. coli & $0 \pm 0$ & $0 \pm 0$ & $11.7 \pm 0.58^{\mathrm{dx}}$ & $12.7 \pm 0.58^{\mathrm{ex}}$ & $19.3 \pm 1.15^{\mathrm{ax}}$ \\
\hline & Klebsiella spp. & $0 \pm 0$ & $0 \pm 0$ & $8.7 \pm 1.15^{\mathrm{dy}}$ & $9.3 \pm 0.58^{\text {ey }}$ & $21.0 \pm 1.00^{\text {ay }}$ \\
\hline & Pseudomonas spp. & $12.3 \pm 0.58^{\mathrm{bz}}$ & $14.3 \pm 1.15^{\mathrm{cz}}$ & $14.3 \pm 0.58^{\mathrm{dz}}$ & $15.7 \pm 1.53^{\mathrm{ez}}$ & $19.7 \pm 0.58^{\mathrm{az}}$ \\
\hline & Vibrio spp. & $0 \pm 0$ & $0 \pm 0$ & $0 \pm 0$ & $8.7 \pm 0.58^{\mathrm{eu}}$ & $18.7 \pm 0.58^{\mathrm{au}}$ \\
\hline & Salmonella spp. & $0 \pm 0$ & $0 \pm 0$ & $8.3 \pm 1.15^{\mathrm{dv}}$ & $10.7 \pm 0.58^{\mathrm{ev}}$ & $20.7 \pm 1.53^{\mathrm{av}}$ \\
\hline & Listeria spp. & $0 \pm 0$ & $8.7 \pm 0.58^{\mathrm{cw}}$ & $12.7 \pm 0.58^{\mathrm{dw}}$ & $13.3 \pm 0.58^{\mathrm{ew}}$ & $20.3 \pm 0.58^{\text {aw }}$ \\
\hline & Staphylococcus spp. & $0 \pm 0$ & $0 \pm 0$ & $7.7 \pm 0.58^{\mathrm{dt}}$ & $10.7 \pm 1.15^{\mathrm{et}}$ & $22.7 \pm 0.58^{\text {at }}$ \\
\hline
\end{tabular}

Values are presened as mean \pm SD. Values with different superscripts within each row are significantly different $(\mathrm{P}<0.05)$. Buffered peptone water, methanol, and ethanol were used as negative controls and found to not affect bacterial growth.

was encountered in 11 instances (Figure 1). On the other hand, the $\mathrm{MBC}$ of the tested spices against the majority of bacterial isolates was $24 \mathrm{mg} / \mathrm{mL}$ (Figure 2). The lowest $\mathrm{MBC}$ was found to be $12 \mathrm{mg} / \mathrm{mL}$ ( in 4 instances), whereas the highest MBC was $48 \mathrm{mg} / \mathrm{mL}$ (in 5 instances). Different studies found varied results for MIC and MBC in spices against microorganisms from different foods (Shan et al., 2007; Dhiman et al., 2016; D'Souza et al., 2017). Chlipala et al.(2010) and Purkait et al.(2018) in their studies found MIC of Clove, Cinnamon, and other spice samples as $<100 \mu \mathrm{g} / \mathrm{mL}$. Bassolé and Juliani(2012) reported MIC of various spices as $0.625-1.25 \mu \mathrm{L} / \mathrm{mL}$

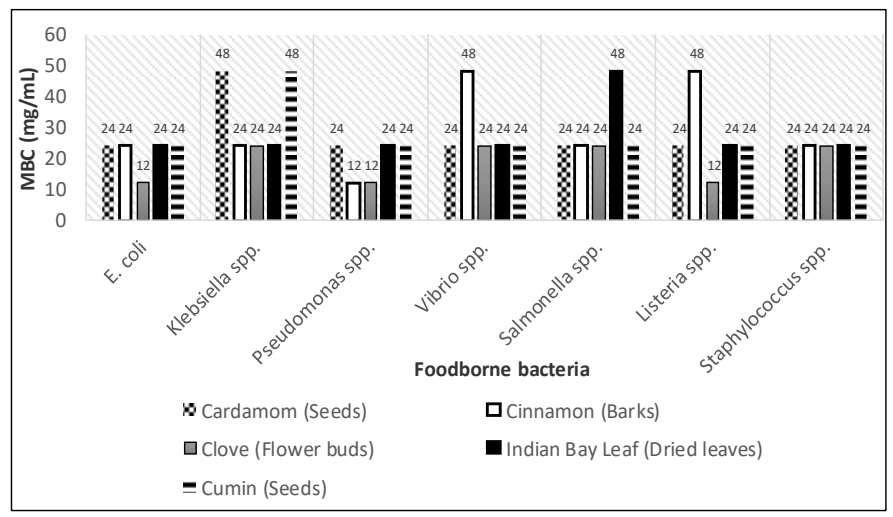

Figure 2. Minimum bactericidal concentration (MBC) of the spice samples. Mean values have been shown here. 
against different bacterial isolates. Dhiman et al.(2016) evident the MIC of spice samples in a range of 25 to 50 $\mathrm{mg} / \mathrm{mL}$.

\section{Conclusion}

The present study confers the presence of considerable antibacterial potential in the tested spices against selected foodborne bacteria. The solvent extracts exhibited strong antimicrobial activity compared to crude and aqueous extracts. Such pieces of evidence indicate that spices could be potent sources of inhibitory substances against food spoilage- and disease-causing microorganisms. The findings inspire us to suggest the uses of spices in the development of effective as well as safe natural food preservatives.

\section{Conflict of interest}

The authors declare no conflict of interest.

\section{Acknowledgement}

The authors would like to thank Stamford University Bangladesh for providing laboratory facilities, technical assistance and financial aid.

\section{References}

Akter, M., Sultana, S. and Munshi, S.K. (2019). Microbiological quality assessment of ready-to-eat fried chicken and chicken soup samples sold in Dhaka Metropolis, Bangladesh. Sumerianz Journal of Biotechnology, 2(7), 48-54.

Al-Jedah, J.H., Ali, M.Z. and Robinson, R.K. (2000). The inhibitory action of spices against pathogens that might be capable of growth in a fish sauce (mehiawah) from the Middle East. International Journal of Food Microbiology, 57(1-2), 129-133. https://doi.org/10.1016/S0168-1605(00)00231-2

Bassolé, I.H.N. and Juliani, H.R. (2012). Essential oils in combination and their antimicrobial properties. Molecules, 17, 3989-4006. https://doi.org/10.3390/ molecules 17043989

Chakraborty, M., Afrin, T. and Munshi, S.K. (2020). Microbiological quality and antimicrobial potential of extracts of different spices. Food Research, 4(2), 375-379. https://doi.org/10.26656/fr.2017.4(2).303

Chlipala, G.E., Sturdy, M., Krunic, A., Lantvit, D.D., Shen, Q., Porter, K., Swanson, S.M. and Orjal, J. (2010). Cylindrocyclophanes with proteasome inhibitory activity from the Cyanobacterium Nostoc sp. Journal of Natural Product, 73, 1529-1537. https://doi.org/10.1021/np100352e

Chouhan, S., Sharma, K. and Guleria, S. (2017).
Antimicrobial activity of some essential oils-present status and future perspectives. Medicines, 4(3), 58. https://doi.org/10.3390/medicines4030058

D'Souza, S.P., Chavannavar, S.V., Kanchanashri, B. and Niveditha, S.B. (2017). Pharmaceutical perspectives of spices and condiments as alternative antimicrobial remedy. Journal of Evidence-Based Complementary and Alternative Medicine, 22(4), 1002-1010. https:// doi.org/10.1177/2156587217703214

de Souza, E.L., Stamford, T., Lima, E.D., Trajano, V.N. and Barbosa, J.M. (2005). Antimicrobial effectiveness of spices: An approach for use in food conservation systems. Brazilian Archives of Biology and Technology, 48(4), 549-558. https:// doi.org/10.1590/S1516-89132005000500007

Dhiman, R., Aggarwal, N., Aneja, K.R. and Kaur, M. (2016). In Vitro antimicrobial activity of spices and medicinal herbs against selected microbes associated with juices. International Journal of Microbiology, 2016, $9015802 . \quad$ https:// doi.org/10.1155/2016/9015802

Gottardi, D., Bukvicki, D., Prasad, S. and Tyagi, A.K. (2016). Beneficial effects of spices in food preservation and safety. Frontiers in Microbiology, 7, 1394. https://doi.org/10.3389/fmicb.2016.01394

Hossain, M.A., Shewly, S.R., Mazumder, C., Arowan, S.M.U.J. and Munshi, S.K. (2020). The occurrence of drug-resistant bacteria and screening the possible presence of residual antibiotics in poultry feed samples. Stamford Journal of Microbiology, 10(1), 30-34. https://doi.org/10.3329/sjm.v10i1.50730

Hossaini, F., Munshi, S.K. and Chakraborty, M. (2020). Antimicrobial effects of different extracts of medicinally used green leafy vegetables collected from local market of Dhaka, Bangladesh. Food Research, 4(3), 860-865. https://doi.org/10.26656/ fr.2017.4(3).017

Hossaini, F., Das, N.C., Hossaini, F., Acharjee, M. and Munshi, S.K. (2021). Antimicrobial traits of different medicinal plants locally available in Bangladesh. Biomedical and Biotechnology Research Journal, 5(1), 1-6.

Jahan, N., Noor, R. and Munshi, S.K. (2018) Microbiological analysis and determination of antimicrobial traits of green banana (Musa spp.) and papaya (Carica papaya). Stamford Journal of Microbiology, 8(1), 41-45. https://doi.org/10.3329/ sjm.v8i1.42439

Kabir, M.I., Ikram, A., Sikder, M.B., Tushar, M.H.H. and Munshi, S.K. (2021). Determination of the inhibitory effects of commercially available homeopathic drugs on pathogenic bacterial growth. 
SVOA Microbiology, 2(1), 1-6.

Leuchner, R.G.K. and Zamparini, J. (2002). Effects of spices on growth and survival of Escherichia coli 0157 and Salmonella enterica serovar Enteritidis in broth model systems and mayonnaise. Food Control, 13(6-7), 399-404. https://doi.org/10.1016/S09567135(02)00051-8

Munshi, S.K., Roy, J. and Noor, R. (2018). Microbiological investigation and determination of the antimicrobial potential of cow dung samples. Stamford Journal of Microbiology, 8(1), 34-37. https://doi.org/10.3329/sjm.v8i1.42437

Negi, P.S. (2012). Plant extracts for the control of bacterial growth: efficacy, stability and safety issues for food application. International Journal of Food Microbiology, 156(1), 7-17. https://doi.org/10.1016/ j.ijfoodmicro.2012.03.006

Noor, R. and Feroz F. (2016). Food safety in Bangladesh: A microbiological perspective. Stamford Journal of Microbiology, 6(1), 33509. https://doi.org/10.3329/sjm.v6i1.33509

Purkait, S., Bhattacharya, A., Bag, A. and Chattopadhyay, R.R. (2018). Antibacterial and antioxidant potential of essential oils of five spices. Journal of Food Quality and Hazards Control, 5(2), 61-71. https://doi.org/10.29252/jfqhc.5.2.6

Savan, E.K. and Kucukbay, Z.F. (2013). Essential oil composition of Elettaria cardamomum Maton. Journal of Applied Biological Sciences, 7(3), 42-45.

Shan, B., Cai, Y.Z., Brooks, J.D. and Corke, H. (2007). The in vitro antibacterial activity of dietary spice and medicinal herb extracts. International Journal of Food Microbiology, 117(1), 112-119. https:// doi.org/10.1016/j.ijfoodmicro.2007.03.003

Sharmin, M., Nur, I.T., Acharjee, M., Munshi, S.K. and Noor, R. (2014). Microbiological profiling and the demonstration of in vitro anti-bacterial traits of the major oral herbal medicines used in Dhaka Metropolis. SpringerPlus, 3, 739. https:// doi.org/10.1186/2193-1801-3-739

Škrinjar, M.M. and Nemet, N.T. (2009). Antimicrobial effects of spices and herbs essential oils. Acta Periodica Technologica, 2009(40), 195 - 209. https://doi.org/10.2298/APT0940195S

Tajkarimi, M.M., Ibrahim, S.A. and Cliver, D.O. (2010). Antimicrobial herb and spice compounds in food. Food Control, 21(9), 1199-1218. https:// doi.org/10.1016/j.foodcont.2010.02.003

Teodoro, A.J. (2019). Bioactive compounds of food: Their role in the prevention and treatment of diseases. Oxidative Medicine and Cellular Longevity, 2019, $3765986 . \quad \mathrm{https} / / /$ doi.org/10.1155/2019/3765986

Wakoli, A.B., Onyango, D.A.O. and Rotich, P.J. (2014). Effect of selected spices on food spoilage rate. Global Journal of Biology, Agriculture and Health Sciences, 3(4), 160-162.

Xu, S.,Yan, F., Ni, Z., Chen, Q., Zhang, H. and Zheng, X. (2014). In vitro and in vivo control of Alternaria alternata in cherry tomato by essential oil from Laurusnobilis of Chineseorigin. Journal of the Science of Food and Agriculture, 94(7), 1403-1408. https://doi.org/10.1002/jsfa.6428

Zhang, H., Kong, B., Xiong, Y.L. and Sun, X. (2009). Antimicrobial activities of spice extracts against pathogenic and spoilage bacteria in modified atmosphere packaged fresh pork and vacuum packaged ham slices stored at $4^{\circ} \mathrm{C}$. Meat Science, 81 (4), 686-692. https://doi.org/10.1016/ j.meatsci.2008.11.011 